\title{
Reproductive biology of the Brazilian blind electric ray Benthobatis kreffti (Chondrichthyes: Narcinidae)
}

\author{
Mariana F. Martins ${ }^{1,2,3}$ and Otto B. F. Gadig ${ }^{2,3}$
}

This study provides information on the reproductive biology of the Brazilian blind electric ray Benthobatis kreffti, endemic to southern and southeastern Brazil. Individuals were caught by bottom trawl carried out in 2003 and 2007, at 492-501 m depth off the São Paulo State continental slope. A total of 152 females $(115-299 \mathrm{~mm})$ and 144 males $(91-243 \mathrm{~mm})$ were sampled. Maturity was first observed at 177 and $162 \mathrm{~mm}$, with total length at $50 \%$ maturity of 191 and $176 \mathrm{~mm}$ in females and males respectively. Uterine fecundity ranged from 1-3 and was not related to female total length. Size at birth estimated from the largest near-term observed embryos and smallest free-swimming ray was $91-100 \mathrm{~mm}$. The low fecundity observed is typical of deepwater elasmobranch species, as well as late maturity in comparison with costal species. The relatively large size-atbirth suggests that this species invests more in length of each embryo than in litter size, increasing the offspring's survival chance. In this context, these parameters highlight the vulnerability of this and other deepwater species to non-natural death, mostly caused by deep-sea fisheries.

Keywords: Deepwater, Fecundity, Size at birth, Size at maturity, Torpediniformes.

Este estudo apresenta informações sobre a biologia reprodutiva da raia elétrica cega brasileira Benthobatis kreffti, endêmica do sul e sudeste brasileiros. Os indivíduos foram capturados com arrasto de fundo, em 2003 e 2007, a 492-501 m de profundidade no talude continental do Estado de São Paulo. Um total de 152 fêmeas (115-299 mm) e 144 machos (91-243 $\mathrm{mm}$ ) foram capturados. A maturidade foi observada em fêmeas de $177 \mathrm{~mm}$ e machos de $162 \mathrm{~mm}$, com o tamanho onde $50 \%$ dos indivíduos encontra-se maduros calculado em $191 \mathrm{~mm}$ (fêmeas) e 176 (machos). O tamanho da prole foi de 1-3 embriões e não foi relacionado ao comprimento materno. $\mathrm{O}$ tamanho ao nascer foi estimado a partir do tamanho do maior embrião à termo e o menor neonato e foi de $91-100 \mathrm{~mm}$. A baixa fecundidade observada é típica de elasmobrânquios de profundidade, bem como a maturidade tardia, comparados com espécies costeiras. O grande tamanho ao nascer sugere que essa espécie investe no tamanho de cada embrião em vez do número de embriões produzidos, aumentando a chance de sobrevivência da prole. Neste contexto, estes parâmetros ressaltam a vulnerabilidade desta e outras espécies de elasmobrânquios a mortes ocasionadas pela pesca em maiores profundidades.

Palavras-chave: Fecundidade, Profundidade, Tamanho ao nascer, Tamanho de primeira maturidade, Torpediniformes.

\section{Introduction}

Elasmobranchs are generally considered as a k-strategy group, being vulnerable to non-natural mortality due to their slow growth, late maturity, low fecundity and long gestation periods, which result in lower rates of population increase and, consequently, susceptibility to overexploitation (Dulvy et al., 2000; Stevens et al., 2000). Deepwater species, compared to coastal and pelagic ones, are even more susceptible since they have slower growth and attain maturity later (IUCN SSC Shark Specialist Group, 2007; García et al., 2008). Therefore, deepwater elasmobranch populations are less productive than coastal species and, subsequently, less resilient (Simpfendorfer, Kyne, 2009).

During the last decades, fisheries have increased efforts in deepwater marine habitats, mostly due to overexploitation of near-shore resources (Roberts, 2002). Deepwater habitats, however, are more susceptible to collapse, and should be considered areas for conservation (Morato et al., 2006). Understanding life history patterns of a species is a powerful tool for its management and conservation once this information is needed to measure the impact of fisheries on elasmobranch populations. In this context,

\footnotetext{
${ }^{1}$ Instituto de Ciências Biológicas, Universidade Federal do Rio Grande-FURG, Av. Itália Km 8, Rio Grande, RS, Brazil. marianadafmartins@ gmail.com, Ohttps://orcid.org/0000-0002-5835-3023 (corresponding author)

${ }^{2}$ Laboratório de Pesquisa de Elasmobrânquios, Instituto de Biociências, Campus do Litoral Paulista-UNESP, Praça Infante Dom Henrique s/nº, 11380-972 São Vicente, São Paulo SP, Brazil. gadig@clp.unesp.br, Đhttps://orcid.org/0000-0002-8109-5085

${ }^{3}$ Instituto de Biociências, Campus de Rio Claro-UNESP, Av. 24 A 1515, 13506-900 Rio Claro, SP, Brazil.
} 
reproductive parameters such as size at maturity, fecundity and reproductive cycle are especially necessary for assessing population status (Walker, 2005).

Electric rays (Order Torpediniformes) represent the third most diverse group among batoids, with about 70 species described (Weigmann, 2016). Numbfishes (Family Narcinidae) are small to moderate size benthic rays occurring in almost all marine regions, inhabiting continental and insular shelves, as well as slopes (e.g. the deepwater genus Benthobatis, which can be found in depths around $1000 \mathrm{~m}$ ) (Carvalho, 1999; McEachran, Carvalho, 2002).

The Brazilian blind electric ray Benthobatis kreffti Rincón, Stehmann \& Vooren, 2001 has a restricted distribution, occurring in the Southwest Atlantic and in southern and southeastern Brazil continental slopes, at 400-600 m depth. This species was studied previously by Rincon (1997, as Benthobatis sp.), and, posteriorly described as a new species by the same author (Rincon et al., 2001). Biological aspects of feeding and reproduction were described for specimens from southern Brazil (Rincon, 1997) and additional specimens were recorded along the Southeast and South Brazilian continental slopes (Bernardes et al., 2005). In southern populations, size at maturity was estimated in $150 \mathrm{~mm}$ and uterine fecundity was estimated in two embryos/female (Rincon et al., 2001). Despite those information, biological data of individuals from the northern portion of its range remains unknown.
Previous described life-history characteristics of $B$. kreffti and the ones presented herein highlight the need to carefully consider this species in management and conservation measures, especially due to its categorization by the IUCN (Rincon, 2004). In this context, considering that deepwater fisheries have increased in the past decades in Brazil (Perez et al., 2003; 2009) and that $B$. kreffti is incidentally captured by squid trawlers (Rincon et al., 2017), impacts of these fisheries in $B$. kreffti populations might be expected. Therefore, the aim of the present study was to analyze the reproductive biology of $B$. kreffti off São Paulo coast, southwestern Atlantic, including its sexual development, size at maturity, fecundity and size at birth.

\section{Material and Methods}

Study area. Individuals were captured in São Paulo State continental slope, Southeast Brazil (Southwest Atlantic), from Cananéia to Santos cities $\left(25^{\circ} 44^{\prime}-25^{\circ} 45^{\prime} \mathrm{S} / 45^{\circ} 09^{\prime}\right.$ $45^{\circ} 11^{\prime} \mathrm{W}$ and $26^{\circ} 09^{\prime}-26^{\circ} 10^{\prime} \mathrm{S} / 45^{\circ} 45^{\prime}-45^{\circ} 47^{\prime} \mathrm{W}$; Fig. 1 ), in four samples (three in July/August 2003 and one in December 2007) from three different sample stations during a research cruise carried out by the São Paulo State University (UNESP) aboard the Brazilian Government Research Vessel "Soloncy Moura". The fishing gear was a bottom trawl, operating between 492-500 m depth. All samples were fixed in buffered formalin $4 \%$ and preserved in ethanol $70 \%$.

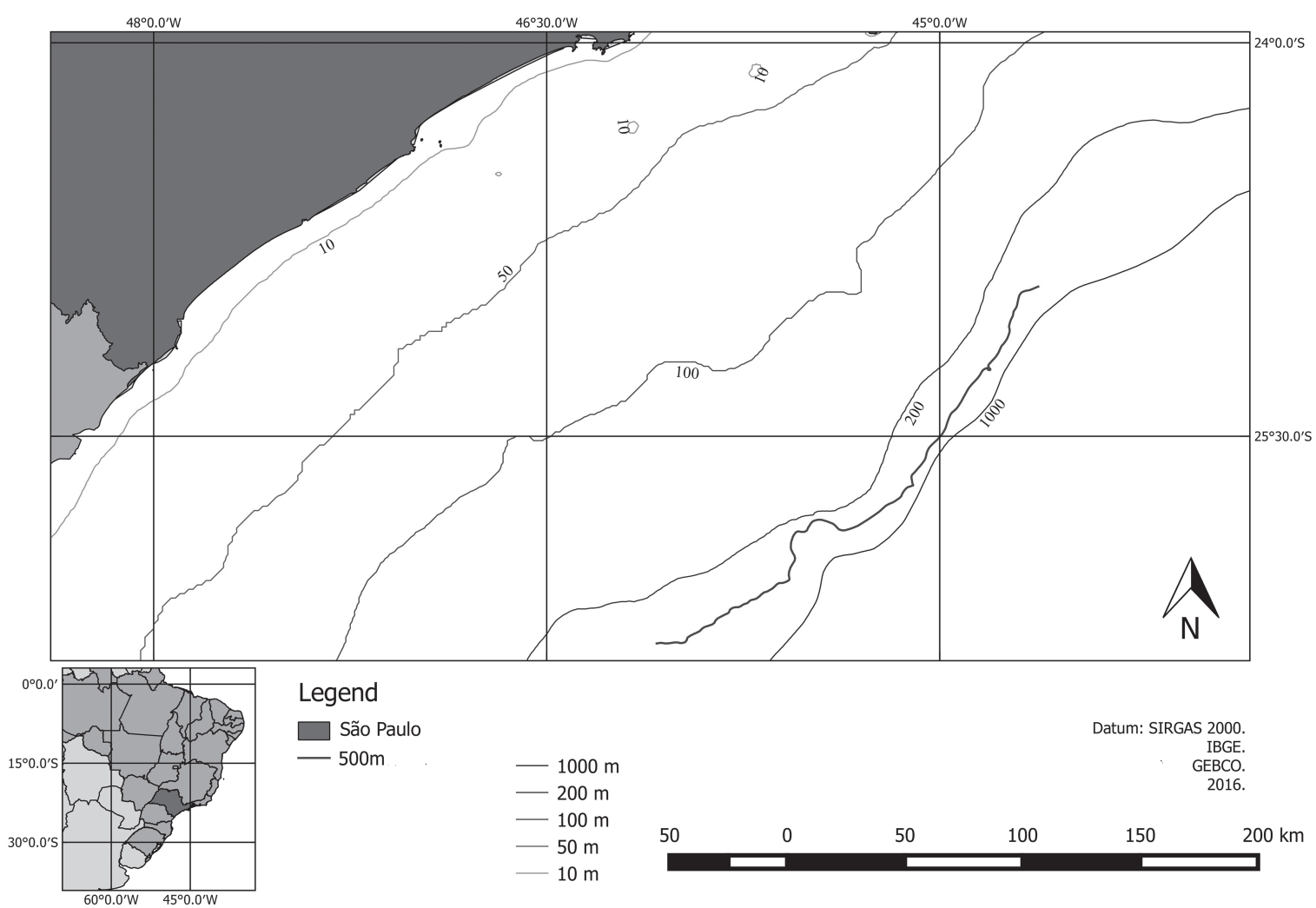

Fig. 1. Studied area where individuals of Benthobatis kreffti were captured off São Paulo State continental slope in 2003 and 2007. Dark grey color represents São Paulo State, in the left-lower square and central square represents São Paulo State continental slope. Thicker grey line indicates the depth where samples were taken $(500 \mathrm{~m})$. 
Biological data recorded at laboratory. Fish total length ( $L_{\mathrm{T}}$, to the nearest $\left.1.0 \mathrm{~mm}\right)$, gonad mass $\left(M_{\mathrm{O}}\right.$ for females and $M_{\mathrm{T}}$ for males, to the nearest $\left.0.001 \mathrm{~g}\right)$, liver mass $\left(M_{\mathrm{L}}\right.$, to the nearest $0.001 \mathrm{~g}$ ) and sex were recorded. Sex identification was based on the presence of claspers. For females, uteri width ( $W_{\mathrm{U}}$, to the nearest $0.01 \mathrm{~mm}$ ), number of ovarian follicles $\left(N_{\mathrm{F}}\right)$ and diameter of the largest ovarian follicle $\left(D_{\mathrm{F}}\right.$, to the nearest $0.01 \mathrm{~mm}$ ) were recorded. Clasper inner length ( $L_{\mathrm{C}}$, to the nearest $0.01 \mathrm{~mm}$ ), clasper gland length $\left(L_{\mathrm{CG}}\right.$, to the nearest $0.01 \mathrm{~mm}$ ) and diameter of largest testicular lobule $\left(D_{\mathrm{L}}\right.$, o the nearest $0.01 \mathrm{~mm}$ ) were recorded for males.

A maturity scale for viviparous elasmobranchs was adapted for use with this species (ICES, 2013). Because Narcinidae batoids do not present macroscopically visible oviducal glands (Prasad, 1945) and due to visualization difficulties of some reproductive organs fixed in formalin and preserved in ethanol $70 \%$ (e.g. vascularization of the uteri and vitellogenic activity in ovarian follicles), maturity stages were condensed and simplified. Maturity stages herein considered were: a) immature, developing and capable to reproduce, for both sexes; and; b) early pregnancy; late pregnancy and post-partum stages for females only. Neonates were considered those individuals with a yolk-sac scar in their abdomen.

Data analysis. Sexual development through maturity stages was analysed by plotting data for sexual characteristics as dependent variables, with $L_{\mathrm{T}}$ as the independent variable. Size at maturity was calculated by fitting binomial data (immature/ mature) to the logistic equation: $Y=\left[1+e^{-(a+b X)}\right]^{-1}$, where $Y$ is the proportion of mature individuals per length class $X$ and $a$ and $b$ are parameters of the equation. Mean size at maturity, which is the size where $50 \%$ of the individuals are mature, was calculated by the ratio: $L_{\mathrm{T} 50}=-a / b$ (Mollet et al., 2000) for both sexes. Ovarian fecundity was estimated by counting the number of ovarian follicles with vitellogenic activity (i.e. vitellogenic follicles) in both ovaries (Fitz, Daiber, 1963; Capapé, Quignard, 1975) and uterine fecundity was calculated based on the number of uterine eggs or embryos in both uteri. Uterine fecundity was represented by the total number of developing embryos or uterine eggs, while litter size was represented by number of near-term embryos. No embryos were observed outside the uteri and abortion events were not observed in the field. In addition, cloacal conditions such as distensions were not observed as well. For this reason, size at birth was estimated based on observations of the smallest free-swimming individuals (neonate) and largest near-term embryos observed.

Male and female gonad symmetry was analyzed with Wilcoxon's paired test, with the null hypothesis being that no difference between mass in left and right structure exists (Zar, 2010). All statistics were carried out using R 3.1 software (www.r-project.org) and a significance level of $5 \%$ was considered. Descriptive statistics for total length in each maturity stages were represented by (mean \pm standard deviation and $n$ represents the sample size).

\section{Results}

Female sexual development. A total of 152 females were analyzed in this study. Immature females ranged from 115 to $184 \mathrm{~mm} L_{\mathrm{T}}(150.0 \pm 20.2 ; n=18)$ and presented two small symmetric ovaries ( $W=2130.5 ; n=89 ; p=0.600)$ lacking macroscopically visible ovarian follicles. Two thread-like oviducts were observed, and uteri were not differentiated from other oviduct portions. Liver mass presented a slow potential growth pattern at this stage.

During the developing maturity stage, females presented developing ovaries, and a few small ovarian follicles could be observed from $167 \mathrm{~mm}$ onward. Uteri were slightly enlarged but virtually not differentiated from the oviduct. A continuous liver mass increase was observed at this stage, following the same potential pattern previously described. Total length ranged from 146 to $215 \mathrm{~mm}(181.1 \pm 18.1 ; n=25)$ at this stage.

The smallest mature female was classified as capable to reproduce and was $177 \mathrm{~mm} L_{\mathrm{T}}$ and maximum $L_{\mathrm{T}}$ recorded for females at this stage was $270 \mathrm{~mm}(220.4 \pm 25.4 ; n=26)$. Uteri were large and clearly differentiated from the oviduct. Both ovaries were functional and had large vitellogenic follicles. At this stage, ovaries attained their maximum mass, with an abrupt increase right after first maturity was observed.

Vitellogenic follicles could still be observed in pregnant females, but were small in size and number. Both uteri were functional and early and late pregnancy stages were characterized by the presence of uterine eggs or embryos, respectively. Total length ranged from 186 to $251 \mathrm{~mm}$ $(216.3 \pm 19.2 ; n=14)$ in early pregancy females and from 201 to $299 \mathrm{~mm}(226.2 \pm 21.6 ; n=33)$ in late pregnancy ones. Liver mass was high for all maturity stages, especially in capable to reproduce females.

In observed post-partum females, uteri were large, flaccid, and some vitellogenic follicles could be observed in both ovaries. Females at this stage had $L_{\mathrm{T}}$ of 195-244 $\mathrm{mm}(220 \pm 12.4 ; \mathrm{n}=32)$. Female reproductive structures are provided in (S1 - Available only as online supplementary file accessed with the online version of the article at http://www. scielo.br/ni) and descriptive statistics and the relation between total length and the sexual variables regarding the observed structures are available in Tab. 1 and Fig. 2a and Fig. 3.

Male sexual development. A total of 114 males were captured. Only one neonate male was observed in this study and was $91 \mathrm{~mm} L_{\mathrm{T}}$. Dissection was not carried out in this individual, though. Immature males ranged from 91 to 179 $\operatorname{mm} L_{\mathrm{T}}(144.7 \pm 17.7 ; n=16)$ and had small, flexible and noncalcified claspers. Clasper glands were hardly differentiated from the adjacent muscular tissue and ducts were straight and thread-like. A three-phase sigmoid growth pattern was observed for $L_{\mathrm{C}}$ and $L_{\mathrm{CG}}$ and immature males had a slow growth pattern. Both testicles were undeveloped and testicles mass increased slowly. Small testicular lobules could be observed in a few individuals at this stage. 
Tab. 1. Descriptive statistics of the sexual variables: liver mass $\left(M_{\mathrm{L}}, \mathrm{g}\right)$, ovaries mass $\left(M_{\mathrm{O}}, \mathrm{g}\right)$, diameter of the largest ovarian follicle $\left(D_{\mathrm{F}}, \mathrm{mm}\right)$, number of ovarian follicles $\left(N_{\mathrm{F}}\right)$ and uteri width $\left(W_{\mathrm{U}}, \mathrm{mm}\right)$ for females of Benthobatis kreffti. Min: minimum value recorded, Max=maximum value recorded, $n$ : sample size and SD: standard deviation.

\begin{tabular}{|c|c|c|c|c|c|c|}
\hline Variable & Maturity Stage & $n$ & Min & Max & Mean & SD \\
\hline \multirow{6}{*}{$M_{\mathrm{L}}$} & Immature & 18 & 0.147 & 1.078 & 0.505 & 0.278 \\
\hline & Developing & 25 & 0.438 & 2.103 & 1.047 & 0.383 \\
\hline & Capable to reproduce & 26 & 1.363 & 3.562 & 2.013 & 0.579 \\
\hline & Early pregnancy & 14 & 0.850 & 1.765 & 1.274 & 0.321 \\
\hline & Late pregnancy & 33 & 0.675 & 3.866 & 1.472 & 0.598 \\
\hline & Post-partum & 33 & 0.581 & 2.210 & 1.441 & 0.462 \\
\hline \multirow{6}{*}{$M_{\mathrm{O}}$} & Immature & 3 & 0.042 & 0.152 & 0.0881 & 0.0574 \\
\hline & Developing & 13 & 0.015 & 0.265 & 0.1022 & 0.0890 \\
\hline & Capable to reproduce & 21 & 0.051 & 3.652 & 0.8724 & 1.0212 \\
\hline & Early pregnancy & 8 & 0.044 & 0.149 & 0.1056 & 0.0352 \\
\hline & Late pregnancy & 16 & 0.031 & 0.271 & 0.1254 & 0.0788 \\
\hline & Post-partum & 26 & 0.025 & 1.111 & 0.1645 & 0.2225 \\
\hline \multirow{6}{*}{$D_{\mathrm{F}}$} & Immature & 0 & & & & \\
\hline & Developing & 8 & 1.45 & 4.83 & 2.887 & 1.208 \\
\hline & Capable to reproduce & 21 & 0.07 & 22.77 & 6.805 & 5.495 \\
\hline & Early pregnancy & 2 & 0.87 & 5.25 & 3.060 & 3.097 \\
\hline & Late pregnancy & 9 & 1.60 & 4.65 & 2.457 & 0.952 \\
\hline & Post-partum & 12 & 0.76 & 6.90 & 3.013 & 1.775 \\
\hline \multirow{6}{*}{$N_{\mathrm{F}}$} & Immature & 0 & & & & \\
\hline & Developing & 3 & 2 & 7 & 3.7 & 2.9 \\
\hline & Capable to reproduce & 15 & 1 & 15 & 4.4 & 3.5 \\
\hline & Early pregnancy & 2 & 1 & 4 & 2.5 & 2.1 \\
\hline & Late pregnancy & 5 & 1 & 8 & 4.2 & 2.8 \\
\hline & Post-partum & 14 & 1 & 10 & 4.3 & 2.6 \\
\hline \multirow{6}{*}{$W_{\mathrm{U}}$} & Immature & 17 & 0.73 & 2.70 & 1.373 & 0.534 \\
\hline & Developing & 25 & 1.00 & 3.92 & 2.202 & 0.721 \\
\hline & Capable to reproduce & 26 & 2.60 & 14.50 & 6.917 & 2.612 \\
\hline & Early pregnancy & 14 & 7.55 & 27.25 & 13.900 & 6.344 \\
\hline & Late pregnancy & 33 & 3.60 & 32.85 & 17.260 & 9.336 \\
\hline & Post-partum & 33 & 2.60 & 15.41 & 8.498 & 3.069 \\
\hline
\end{tabular}
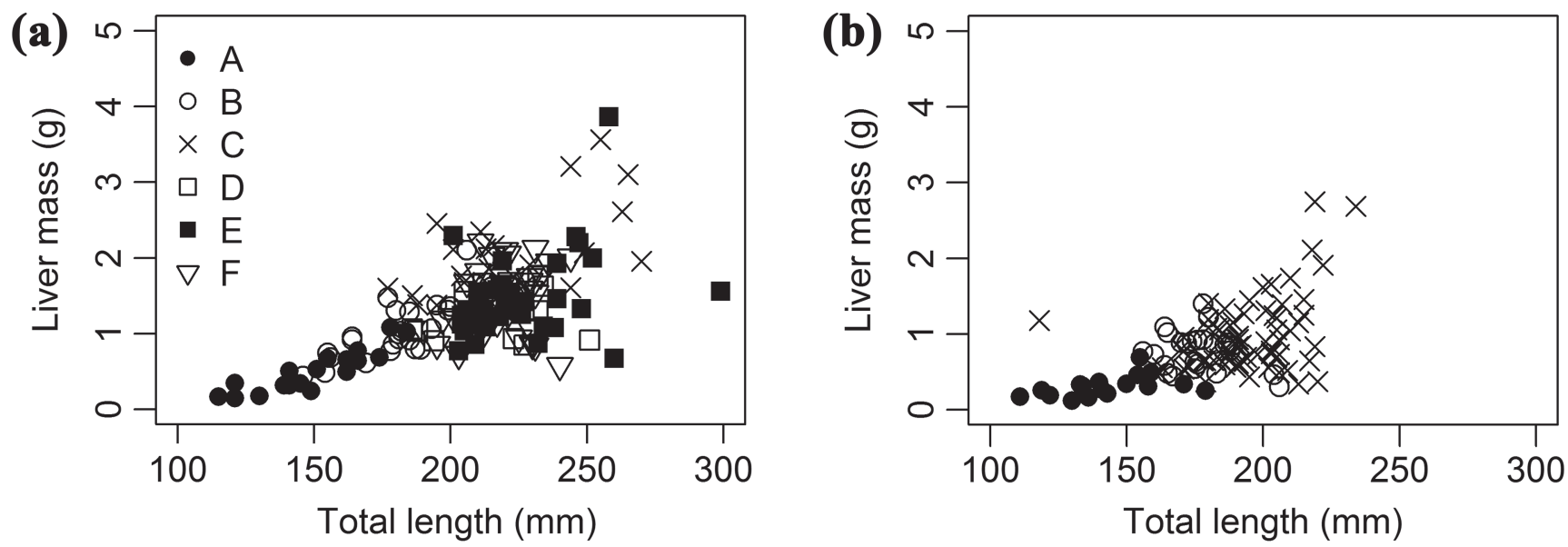

Fig. 2. Relationship between total length and liver mass for a. females and b. males of Benthobatis kreffti from São Paulo State continental slope, Brazil. Maturity stages considered were: (A) immature, (B) developing, (C) capable to reproduce (females and males), and (D) early pregnancy, (E) late pregnancy and (F) post-partum (females only). 
(a)

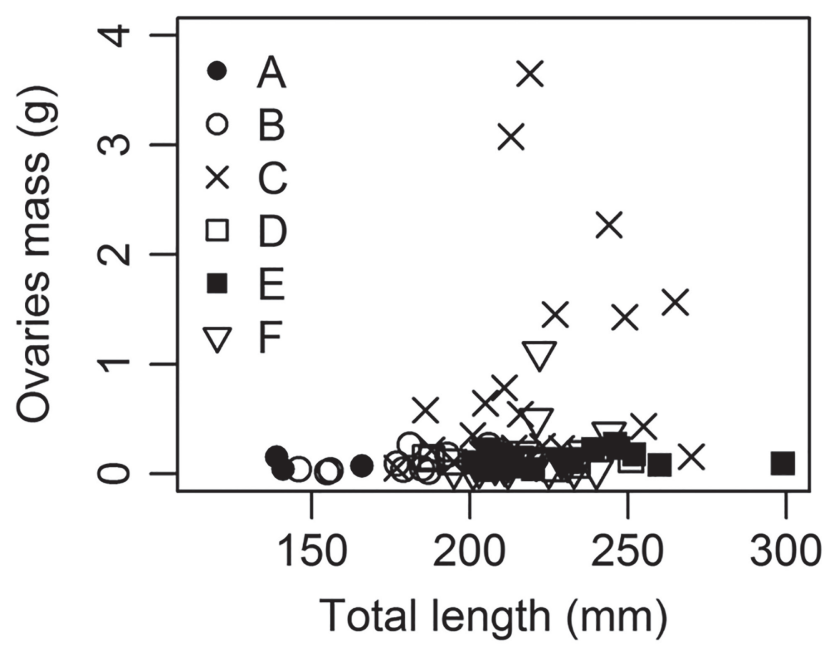

(b)

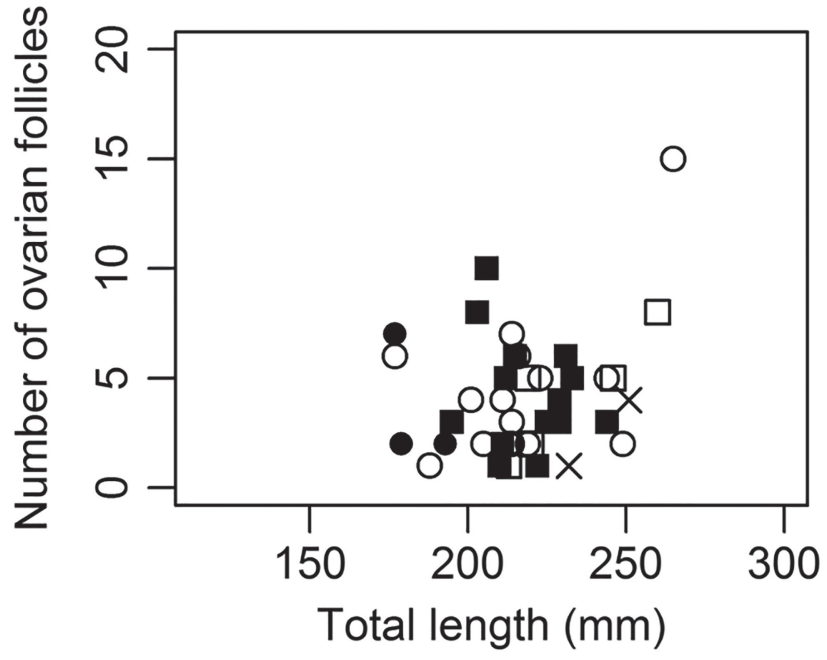

(c)

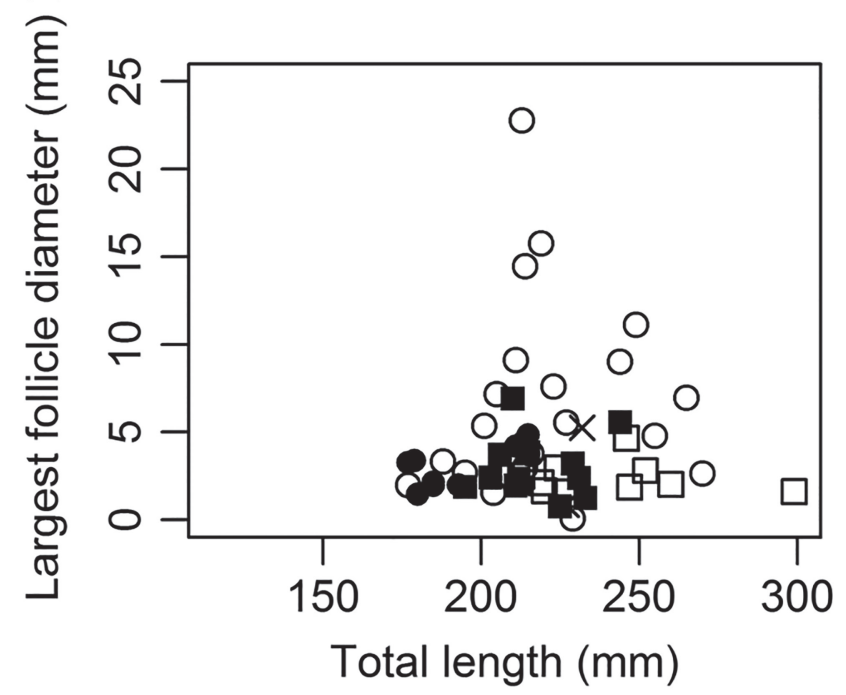

(d)

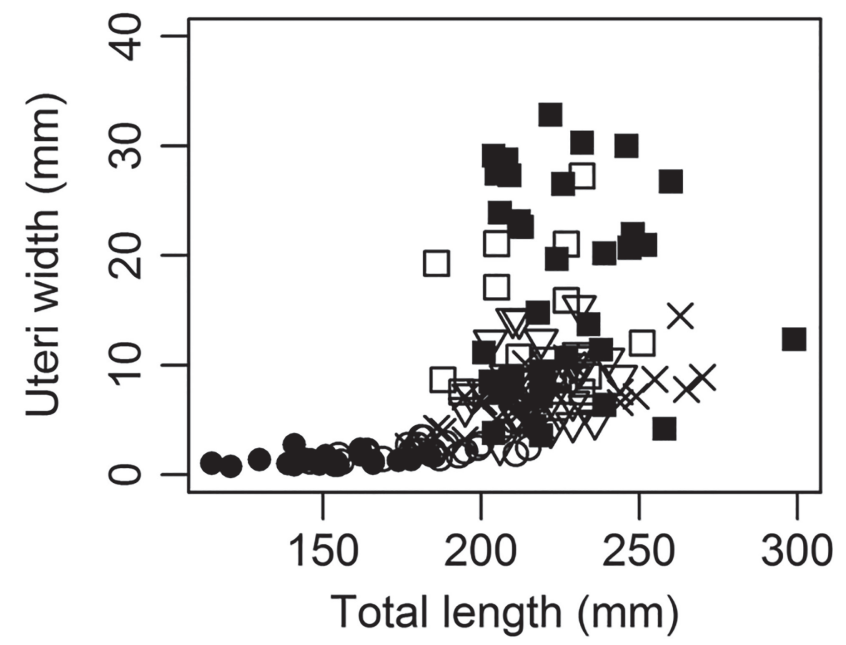

Fig. 3. Relationship between total length and a. ovaries mass; b. number of vitellogenic follicles; c. largest follicle diameter and d. uteri width of females of Benthobatis kreffti from São Paulo State continental slope, Brazil. Maturity stages considered were: (A) immature, (B) developing, (C) capable to reproduce, (D) early pregnancy, (E) late pregnancy, and (F) post-partum.

Total length ranged from 156 to $206 \mathrm{~mm}(176.8 \pm 12.3$; $n=25$ ) in developing males. At this stage, claspers were still non-calcified, but testicular lobules, and coiled ducts were observed in those individuals. Clasper glands could be distinguishable from the adjacent muscular tissue and a rapid growth of these structures, as well as claspers was observed at this stage. Testicles and liver mass increased abruptly at this stage, as well as $L_{\mathrm{C}}$ and $L_{\mathrm{CG}}$.

Capable to reproduce males were observed from 162 $\mathrm{mm}$ to $234 \mathrm{~mm} L_{\mathrm{T}}(195.0 \pm 15.6 ; n=68)$, and had fully calcified claspers, enlarged clasper glands and fully coiled ducts. Difficulties in observing sperm within the ducts were attributed to fixation. Claspers and clasper glands showed a slow growth, representing the plateau of the sigmoid pattern observed for $L_{\mathrm{C}}$ and $L_{\mathrm{CG}}$ growth. An abrupt mass increase in testicles was observed at this stage and enlarged testicular lobules were observed in both testicles. However, testicles were asymmetric $(W=387.5 ; n=107 ; \mathrm{p}=0.003)$. Males reproductive structures are provided in (S2 - Available only as online supplementary file accessed with the online version of the article at http://www.scielo.br/ni) and descriptive statistics and the relation between total length and the sexual variables regarding the observed structures are available in Tab. 2 and Fig. 2b and Fig. 4.

Size at maturity. Size at maturity $\left(L_{\mathrm{T} 50}\right)$ was $191.1 \mathrm{~mm} L_{\mathrm{T}}(95 \%$ c.i.:186.3-195.4) for females, representing $63 \%$ of maximum total length recorded (Fig. 5a). Size at maturity $\left(L_{\mathrm{T} 50}\right)$ was $176.3 \mathrm{~mm} L_{\mathrm{T}}$ for males (95\% c.i.: 170.4-181.4) and represented $75.3 \%$ of the maximum total length recorded (Fig. $5 b$ ). 
Tab. 2. Descriptive statistics of the sexual variables: liver mass $\left(M_{\mathrm{L}}, \mathrm{g}\right)$, clasper length $\left(L_{\mathrm{C}}, \mathrm{mm}\right)$, clasper gland length $\left(L_{\mathrm{CG}}\right.$, $\mathrm{mm})$, testicles mass $\left(M_{\mathrm{T}}, \mathrm{g}\right)$, and diameter of the largest testicular lobule $\left(D_{\mathrm{L}}, \mathrm{mm}\right)$ for males of Benthobatis kreffti. Min: minimum value recorded, Max=maximum value recorded, $n$ : sample size and SD: standard deviation.

\begin{tabular}{|c|c|c|c|c|c|c|}
\hline Variable & Maturity Stage & $n$ & Min & $\operatorname{Max}$ & Mean & SD \\
\hline \multirow{3}{*}{$M_{\mathrm{L}}$} & Immature & 17 & 0.119 & 0.688 & 0.3082 & 0.1400 \\
\hline & Developing & 25 & 0.301 & 1.400 & 0.7791 & 0.2593 \\
\hline & Capable to reproduce & 69 & 0.340 & 2.750 & 0.9830 & 0.4835 \\
\hline \multirow{4}{*}{$L_{\mathrm{C}}$} & Neonate & 1 & 2.69 & 2.69 & 2.685 & 0.000 \\
\hline & Immature & 17 & 3.03 & 11.10 & 5.861 & 2.818 \\
\hline & Developing & 25 & 10.92 & 15.00 & 12.370 & 1.003 \\
\hline & Capable to reproduce & 68 & 8.23 & 18.77 & 14.080 & 1.425 \\
\hline \multirow{3}{*}{$L_{\mathrm{CG}}$} & Immature & 9 & 1.90 & 8.00 & 5.376 & 2.174 \\
\hline & Developing & 25 & 7.05 & 11.22 & 9.045 & 1.257 \\
\hline & Capable to reproduce & 68 & 7.67 & 14.84 & 10.380 & 1.286 \\
\hline \multirow{3}{*}{$M_{\mathrm{T}}$} & Immature & 12 & 0.001 & 0.014 & 0.0313 & 0.0314 \\
\hline & Developing & 25 & 0.051 & 0.331 & 0.0998 & 0.0680 \\
\hline & Capable to reproduce & 67 & 0.036 & 0.315 & 0.1627 & 0.0675 \\
\hline \multirow{3}{*}{$D_{\mathrm{L}}$} & Immature & 3 & 0.235 & 0.340 & 0.2917 & 0.0530 \\
\hline & Developing & 16 & 0.275 & 0.770 & 0.4381 & 0.1425 \\
\hline & Capable to reproduce & 61 & 0.275 & 1.260 & 0.6095 & 0.1944 \\
\hline
\end{tabular}

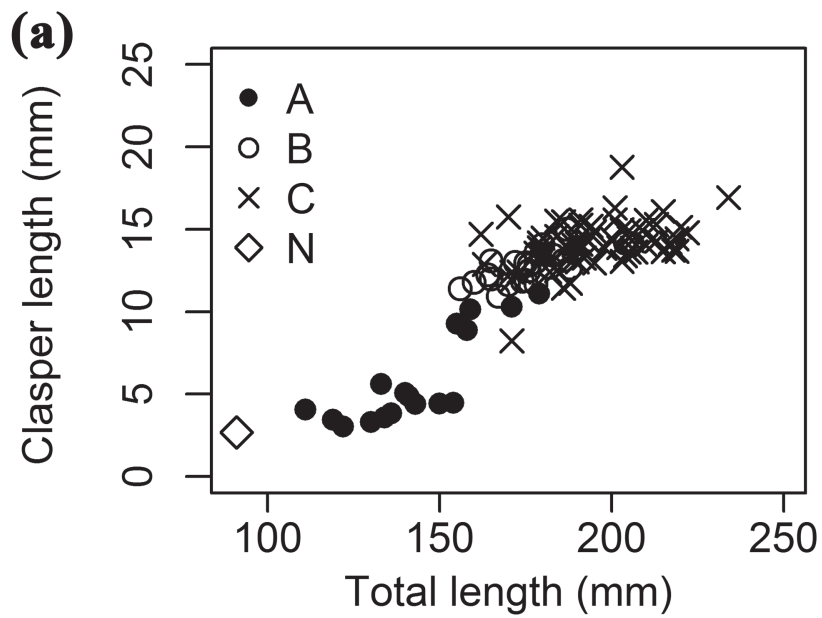

(b)

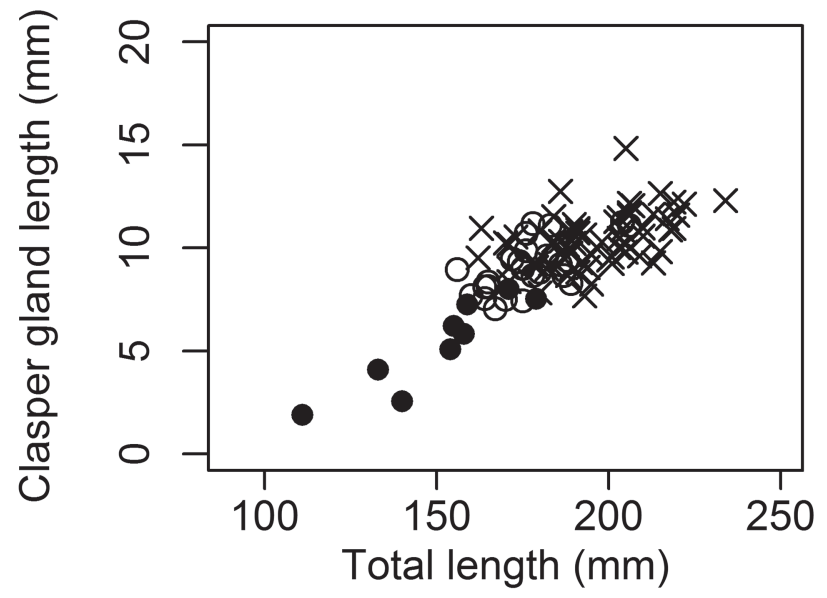

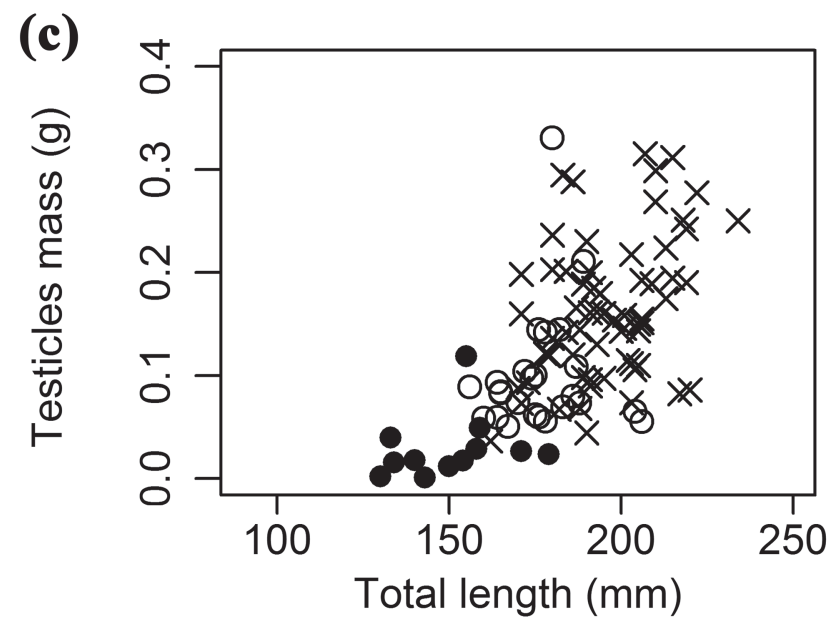

(d)

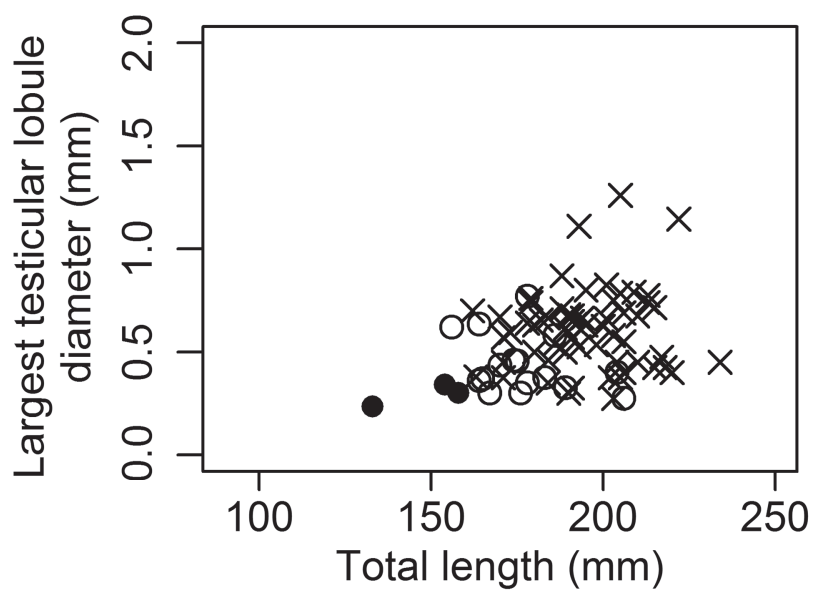

Fig. 4. Relationship between total length and a. clasper length; b. clasper gland length; c. testicles mass, and d. largest testicular lobule diameter of males of Benthobatis kreffti from São Paulo State continental slope, Brazil. Maturity stages considered were: $(\mathrm{N})$ neonate, $(\mathrm{A})$ immature, $(\mathrm{B})$ developing, and $(\mathrm{C})$ capable to reproduce. 
(a)

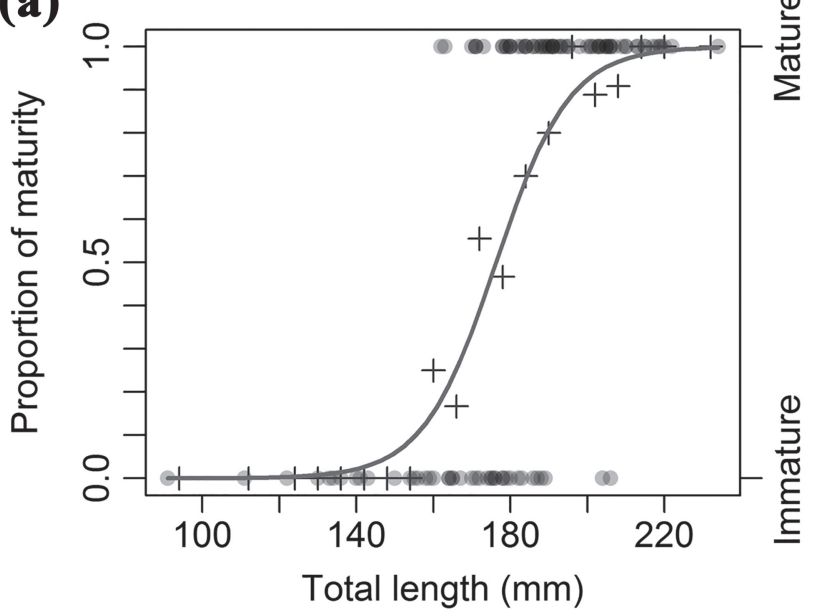

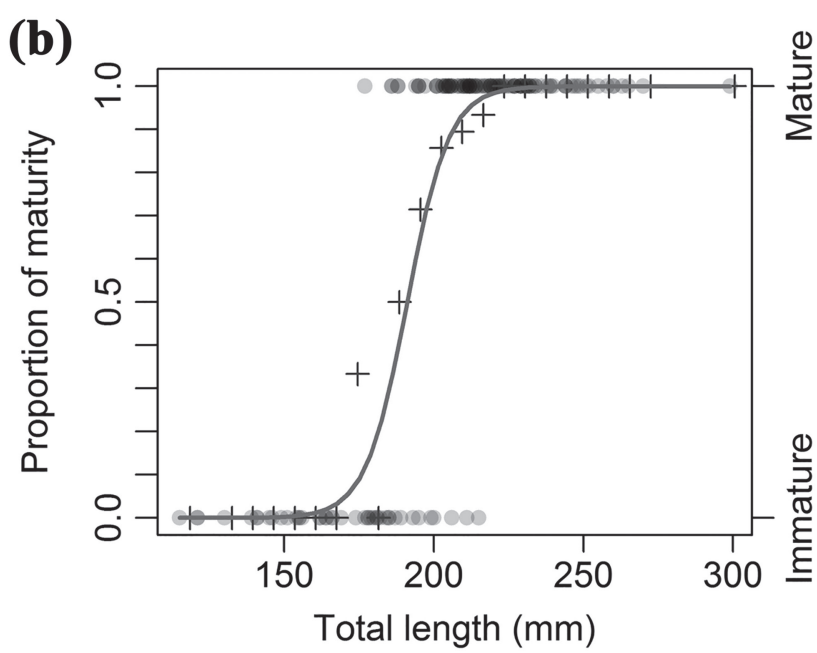

Fig. 5. Mean size at maturity for a. males and b. females of Benthobatis kreffti from São Paulo State continental slope, Brazil.

Fecundity. Capable to reproduce females presented mean ovarian fecundity of 4.4 vitellogenic follicles per female (S.D. $=3.5 ; n=15)$, ranging from one to 15 follicles. Uterine fecundity ranged from one to three embryos or eggs per female. Uterine eggs were covered by a thin membrane which was absent in llate pregnancy females and were observed in 14 females and just one in each female. Embryos were observed in 33 females and both uteri were functional. Twelve females had uterine fecundity $\geq 2$, with $58.3 \%$ presenting embryos in both uteri and $41.7 \%$ with two embryos in one uterus.

No evident relationship between uterine fecundity and total length was observed, although smaller females presented only one embryo and larger females presented two or three embryos (Fig. 6). In addition, a high overlap of females bearing one and two embryos was observed between 204 and $248 \mathrm{~mm} L_{\mathrm{T}}$ and maximum fecundity (three embryos/female) was observed in females of 252 and $258 \mathrm{~mm} L_{\mathrm{T}}$.

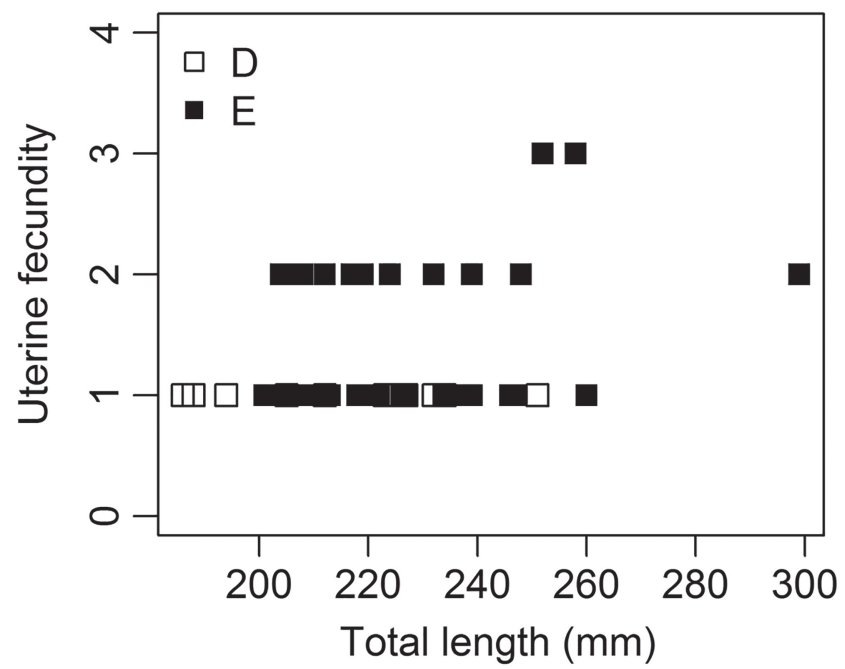

Fig. 6. Relationship between total length and fecundity for Benthobatis kreffti from São Paulo State continental slope, Brazil, considering (D) early pregnancy and (E) late pregnancy females.
Size at birth. Embryos had total length ranging from 14 to $100 \mathrm{~mm} \mathrm{~L}_{T}(73.0 \pm 22.4, n=37)$. Near-term embryos were 91$100 \mathrm{~mm} L_{\mathrm{T}}$, with female ones being 91-96 $\mathrm{mm} L_{\mathrm{T}}(n=4)$ and males presenting $L_{\mathrm{T}}$ of $95 \mathrm{~mm}(n=1)$. One male neonate of $91 L_{\mathrm{T}}$ was observed.

\section{Discussion}

Reproductive knowledge is essential for management and conservation plans (Walker, 2005). Yet, information about the reproductive biology of Brazilian deepwater elasmobranchs is scarce due to the lack of individuals discharged and also low commercial value of this group. Benthobatis kreffti is the only species of this genus occurring in the Southwest Atlantic, being relevant for the local ichthyofauna. Since little biological information is available for this species, no predictions can be provided under an overfishing scenario. This, added to its limited geographic distribution, indicates a potential vulnerability of this species.

Sexual development started with follicle growth in ovaries, followed by uteri enlargement in females, around $170 \mathrm{~mm} L_{\mathrm{T}}$, and maturity onset at $177 \mathrm{~mm} L_{\mathrm{T}}$. Maturity was first observed at $162 \mathrm{~mm} L_{\mathrm{T}}$ in males, with clasper gland and lobules enlargement, followed by an increase in testes mass. Benthobatis kreffti seems to have an abrupt transition from developing to capable to reproduce stages, within a limited total length range, as observed for other deepwater elasmobranchs species (Rigby et al., 2016). Since deepwater fishes tend to present slower metabolisms (Koslow, 1996) resulting in slower growth and late maturity, is reasonable to suggest that this abrupt transition reflects the habitat where this species occurs.

Rincon (1997) observed only one functional ovary in specimens of $B$. kreffti from southern Brazil. Torpediniformes present, however, usually present two functional ovaries, as observed in this study and for Torpedo torpedo (Linnaeus, 1758) (Capapé et al., 2000), 
Tetronarce californica (Ayres, 1855) (Neer, Cailliet, 2001), Narcine bancroftii (Griffith \& Smith, 1834) (Moreno et al., 2010) and Narcine entemedor Jordan \& Starck, 1895 (Burgos-Vázquez et al., 2017). Differences in reproductive functionality have been reported between species for the genus Squatina (Vooren, Da Silva, 1991), however, differences in the number of gonads between populations was never reported for elasmobranchs. Further studies are needed to understand if there is an intraspecific variation in gonad functionality between southern and southeastern Brazilian populations of $B$. kreffti.

Gonad mass increased abruptly as a function of $L_{\mathrm{T}}$ at larger developing individuals, suggesting that reproductive investment occurs in a short period before maturation and continues increasing, slowly, in mature individuals. Rapid gonad growth may reflect a reproductive strategy related to metabolism and slow growth of deepwater species due to low temperatures of deeper waters (Rigby et al., 2016). Capable to reproduce females had the heaviest ovaries, followed by post-partum ones. During early pregnancy, a rapid decrease in $M_{\mathrm{O}}$ was observed, followed by a recovery in late pregnancy and post-partum stages, suggesting that mating does not immediately follows parturition. The same pattern was observed for Tetronarce nobiliana (Bonaparte, 1835), with females presenting distended uteri and vitellogenic activity (Capapé et al., 2006) and for Narcine brasiliensis (Olfers, 1831) (VillavicencioGarayazar, 1993). Capapé et al. (2001), however, found gravid females of Torpedo mackayana Metzelaar, 1919 with degenerating oocytes.

Liver mass rapidly decreased during early-pregnancy, and increased for post-partum females, achieving its maximum at capable to reproduce females. Vitellogenic activity starts, especially, in late-pregnancy and postpartum stages but at capable to reproduce stages, females have larger livers than in any other stage, being synchronous with ovaries mass increase. Such a synchronous growth between liver and gonad mass is expected once yolk plays an important role during the whole embryo development for B. kreftti (Hamlett et al., 2005).

Clasper length presented a sigmoid growth pattern, with a slow growth, followed by a rapid growth and finally a slow growth, when individuals reach maturity, similar to other elasmobranchs (Parsons, 1983; Costa et al., 2005; Oddone et al., 2008; Ebert et al., 2008). In clasper gland length, the same sigmoid growth pattern was observed and, considering the secretory function of the clasper gland related to copulatory activity (Piercy et al., 2006), a synchronous growth is expected for both structures.

Size at maturity was different between sexes, with females attaining maturity at larger lengths than males (191.1 $\mathrm{mm}$ in females and $176.3 \mathrm{~mm}$ in males). Sexual differences in $L_{T 50}$ are common among elasmobranchs, including Narcinidae family (Moreno et al., 2010; Rolim et al., 2015) and this delay in maturity may reflect the reproductive cost of females, such as vitellogenesis and embryo nutrition, for example (Cortés, 2000). In addition, attaining larger sizes may represent a reproductive advantage to females regarding embryo development and growth within the uterus.

Specimens from southern Brazil mature, in general, at $150 \mathrm{~mm}$ for both sexes (Rincon et al., 2001), whereas in this study, maturity was first observed at $177 \mathrm{~mm}$ and $162 \mathrm{~mm}$ for females and males, respectively. Such discrepancies may be a result of different methods for maturity estimates or, in fact, an evidence of two distinct populations, as observed for Mustelus manazo Bleeker, 1855 by Yamaguchi et al. (2000). In this case, molecular analyses would be necessary to elucidate such questions.

Benthobatis kreffti attains maturity at $63 \%$ and $73 \%$ of total length for females and males respectively, suggesting a late maturation. Although age-estimation studies have not been yet carried out for this species, it is known that late maturation is associated with long life-span (Roberts, 2002). In addition, elasmobranchs present a relative late maturation (Cortés, 2000), with several species maturing at $>60 \%$ of the total body length (Mejía-Falla et al., 2012; Clarke et al., 2014). Late maturity, added to a possible longevity of this species make then vulnerable to nonnatural deaths (Cortés, 2000), highlighting the need of studies concerning biology parameters for eventual management and conservation plans.

Litter size recorded for Benthobatis kreffti was low in comparison with other Torpediniformes (Capapé et al., 2006; Moreno et al., 2010; Rolim et al., 2015). El Kamel-Moutalibi et al. (2011) found 1-13 embryos/female in Torpedo torpedo, whilst Burgos-Vázquez et al. (2017) observed 1-24 embryos in Narcine entemedor. Such differences in fecundity among Torpediniformes might suggest that low fecundity is more related to depth than to phylogenetic relationships. Litter size in this study was also different than the one observed for $B$. kreffti in southern Brazil (Rincon, 1997). The low fecundity observed for $B$. kreffti and other deepwater species, highlights that deepwater Chondrichthyes are less fecund than coastal species and might be even more vulnerable to fishing mortality (García et al., 2008).

Differences in ovarian fecundity and number of uterine eggs or embryos were observed for B.kreffti, as already reported for several elasmobranchs. Consalvo et al. (2007) observed 2-22 ovarian follicles but 4-19 embryos in $T$. torpedo, whereas, for T. marmorata, ovarian follicles ranged from one to 35 and litter size was 3-16. These differences are probably a result of reabsorption events once not all follicles are ovulated and might undergo atresia (Conrath, 2005).

Near-term embryos (i.e. fully developed embryos without yolk-sac) were observed from 90 to $100 \mathrm{~m} L_{\mathrm{T}}$ and one neonate was observed with $91 \mathrm{~mm} L_{\mathrm{T}}$. Therefore, birth may occur when embryos attain $90-100 \mathrm{~mm}$ total length. Benthobatis kreffti invests in size of each embryo, rather than litter size. Therefore, despite its low fecundity, neonates are $1 / 3$ of the mother size and might have better 
chances of survival. Narcine brasiliensis size at birth was estimated at 110-112 $\mathrm{mm} L_{\mathrm{T}}$, while females attain $840 \mathrm{~mm}$ $L_{\mathrm{T}}$ (Villavicencio-Garayzar, 1993). Other Torpediniformes also present smaller relative size at birth, with term embryos being approximately $20 \%$ of maximum total length recorded (Capapé et al., 2001; Capapé et al., 2006). Such strategy of producing large neonates as observed in this study may not be a characteristic in common among Torpediniformes, but specifically of this species due to its habitat.

In conclusion, B. kreffti presents a relative low fecundity, but large size at birth. This strategy seems to be advantageous in a non-explored environment. However, under circumstances of deep-sea exploration, these reproductive aspects may affect recruitment success, making this species vulnerable. In addition, after attaining maturity, females seem to, rapidly, contribute to the population increase, since a short period of body growth is observed in the mean $L_{\mathrm{T}}$ between capable to reproduce and pregnant females. Reproductive investment in gonad increase occurs right before maturity is reached, indicating that this species may invest in somatic growth during most of the immature and developing stages.

This study provides information about the reproductive biology of the rare and unknown southeastern benthic elasmobranch species, B. kreffti, from the southeastern Brazilian slope. Life history differences were observed between the southern and southeastern populations highlighting the need to consider these populations differently for management and conservation purposes. Several studies show that populations present a wide variation in life-history patterns, including size at maturity (Yamaguchi et al., 2000; Capapé et al., 2006; Farrel et al., 2010 ) and that could be the reason of such differences in $B$. kreffti studies. Additional biological studies, considering larger samples and including molecular approach are needed to understand the population structure.

\section{Acknowledgments}

This study was financed in part by the Coordenação de Aperfeiçoamento de Pessoal de Nível Superior - Brasil (CAPES) - Finance Code 001. O.B.F. Gadig is supported by the National Council for Scientific and Technological Development (CNPq - \# 308430/2015-8).

\section{References}

Bernardes RA, Figueiredo JL, Rodrigues AR, Fischer LG, Vooren CM, Haimovici M, Rossi-Wongtschowski CLDB. Peixes da zona econômica exclusiva da região sudeste-sul do Brasil: levantamento com armadilhas, pargueiras e rede de arrasto de fundo. São Paulo: Edusp; 2005.

Burgos-Vázquez MI, Mejía-Falla PA, Cruz-Escalona VH, BrownPeterson NJ. Reproductive strategy of the giant electric ray in the southern gulf of California. Mar Coast Fish. 2017; 9(1):577-96.
Capapé C, Quignard JP. Essai d'évaluation de la fécondité chez les sélaciens ovipares: cas de Raja miraletus Linné, 1758 et de $R$. radula Delaroche, 1809 des côtes tunisiennes. Arch Inst Pasteur de Tunis. 1975; 52(3):263-76.

Capapé C, Seck AA, Diatta Y. Reproductive biology of the common torpedo, Torpedo torpedo (Linnaeus, 1758) (Pisces, Torpedinidae) from the coast of Senegal (Eastern Tropical Atlantic). Miscelània Zool. 2000; 23(1):9-21.

Capapé C, Seck AA, Diatta Y, Diop M. Observations on the reproductive biology of Torpedo (Tetronarce) mackayana (Torpedinidae), from the coast of Senegal (Eastern tropical Atlantic). Cybium. 2001; 25(1):95-99.

Capapé C, Guélorget O, Vergne Y, Quignard JP, Ben Amor MM, Brandaï MN. Biological observations on the black torpedo, Torpedo nobiliana Bonaparte 1835 (Chondrichthyes: Torpedinidae), from two mediterranean areas. Ann Ser Hist Nat. 2006; 16(1):19-28.

Carvalho MR. A synopsis of the deep-sea genus Benthobatis Alcock, with a redescription of the new type species Benthobatis moresbyi Alcock 1898 (Chondrychthyes, Torpediniformes, Narcinidae). Soc Fr Ichthyol. 1999; 231-255.

Clarke TM, Espinoza M, Wehrtmann IS. Reproductive ecology of demersal elasmobranchs from a data-deficient fishery, Pacific of Costa Rica, Central America. Fish Res. 2014; 157:96-105.

Conrath CI. Reproductive biology. In: Musick JA, Bonfil R, editors. Management and techniques for elasmobranch fishes. Rome: FAO; 2005, p.103-126.

Consalvo I, Scacco U, Romanelli M, Vacchi M. Comparative study on the reproductive biology of Torpedo torpedo (Linnaeus, 1758) and T. marmorata (Risso, 1810) in the central Mediterranean Sea. Sci Mar. 2007: 71(2):213-22.

Cortés E. Life history patterns and correlations in sharks. Rev Fish Sci Aquac. 2000; 8(4):299-344.

Costa ME, Erzini K, Borges TC. Reproductive biology of the black mouth catshark, Galeus melastomus (Chondrichthyes: Scyliorhinidae) of the south coast of Portugal. J Mar Biol Assoc UK. 2005; 85(5):1173-83.

Dulvy NK, Metcalfe JD, Ganville J, Pawson MG, Reynolds JD. Fishery stability, local extinctions, and shifts in community structure in skates. Conserv Biol. 2000; 14(1):283-93.

Ebert DA, Compagno LJV, Cowley PD. Aspects of the reproductive biology of skates (Chondrichthyes: Rajiformes: Rajoidei) from southern Africa. ICES J Mar Sci. 2008; 65:81-102.

El Kamel-Moutalibi O, Mnarsi N, Boumaïza M, Ben Amor MM, Reynaud C, Capapé C. Maturity, reproductive cycle and fecundity of common torpedo, Torpedo torpedo (Chondrichthyes, Torpedinidae) from the Lagoon of Bizerte (Northeastern Tunisia, Central Mediterranean. J Ichthyol. 2013; 53(9):758-74.

Farrel ED, Marinani S, Clarke MW. Reproductive biology of the starry smooth-hound shark Mustelus asterias: geographic variation and implications for sustainable exploitation. J Fish Biol. 2010; 77(7):1505-25.

Fitz ES, Daiber FC. An introduction to the biology of Raja eglanteria Bosc 1800 and Raja erinacea Mitchill, 1825 as they occur in Delaware Bay. Bull Bing Ocean Coll. 1963; 18(3):69-97. 
García VB, Lucifora LO, Myers RA. The importance of habitat and life history to extinction risk in sharks, skates, rays and chimaeras. Proc R Soc Lond B Biol Sci. 2008; 275(1630):83-89.

Hamlett WC, Kormanik G, Storrie M, Stevens B, Walker TI. Chondrichthyan parity, lecithotrophy and matrotrophy. In: Hamlett WC, editor. Reproductive biology and phylogeny of Chondrichthyes: sharks, batoids and chimaeras, volume 3. Enfield (NH): Science Publishers Inc.; 2005. p.395-434.

ICES. 2013. Report of the workshop on sexual maturity staging of elasmobranchs (WKMSEL), 11-14 December 2012, Lisbon, Portugal. ICES CM 2012/ACOM:59. 68 pp.

IUCN SSC Shark Specialist Group. A collation and summarization of available data on deepwater chondrichthyans: biodiversity, life history and fisheries. Australia: Marine Conservation Biology Institute; 2007. 137p.

Koslow JA. Energetic and life-history patterns of deep-sea benthic, benthopelagic and seamont-associated fish. J Fish Biol. 1996; 49(Supp.A):54-74.

McEachran JD, Carvalho MR. Batoid fishes. In: Carpenter K, editor. The living marine resources of the Western Central Atlantic - Volume 1: i ntroduction, molluscs, crustaceans, hagfishes, sharks, batoid fishes and chimaeras. Rome: FAO; 2002. (FAO Species Identification Guide for Fishery Purposes and American Society of Ichthyologists and Herpetologists. Special Publication; No. 5). p.508-589.

Mejía-Falla PA, Navia AF, Cortés E. Reproductive variables of Urotrygon rogersi (Batoidea: Urotrygonidae): a species with a triannual reproductive cycle in the eastern tropical Pacific Ocean. J Fish Biol. 2012; 80(5):1246-66.

Mollet HF, Cliff G, Pratt Jr HL, Stevens JD. Reproductive biology of the female shortfin mako, Isurus oxyrinchus Rafinesque, 1810, with comments on the embryonic development of lamnoids. Fish Bull. 2000; 98(2):299-318.

Morato T, Watson R, Pitcher TJ, Pauly D. Fishing down the deep. Fish Fish. 2006; 7(1):24-34.

Moreno F, Acevedo K, Grijalba-Bendeck M, Acero A, Paramo J. Reproducción de la raya eléctrica Narcine bancroftii (Torpediniformes:Narcinidae) en Santa Marta, Caribe colombiano. Lat Am J Aquat Res. 2010; 38(1):27-36.

Musick JA, Ellis JK. Reproductive evolution of chondrichthyans. In: Hamlett WC, editor. Reproductive biology and phylogeny of Chondrichthyes: sharks, rays and chimaeras, volume 3. Enfield (NH): Science Publishers Inc.; 2005. p.45-79.

Neer JA, Cailliet GM. Aspects of the life history of the Pacific electric ray, Torpedo californica (Ayres). Copeia. 2001; 2001(3):842-47.

Oddone MC, Norbis W, Mancini PL, Amorim AF. Sexual development and reproductive cycle of the eyespot skate Atlantoraja cyclophora (Regan, 1903) (Chondrichthyes: Rajidae: Arhynchobatinae), in southeastern Brazil. Act Adriat. 2008; 49(1):73-87.

Parsons GR. The reproductive biology of the atlantic sharpnose shark Rhizoprionodon terranovae (Richardson). Fish Bull. 1983; 81(1):61-73.

Prasad RR. Further observations on the structure and function of the nidamental glands of a few elasmobranchs of the Madras coast. P Indian Acad Sci B. 1945; 22:368-73.
Perez JAA, Wahrlich R, Pezzuto PR. Chartered trawling on the brazilian slope. Mar Fish Rev. 2009; 71(2):24-36.

Perez JAA, Wahrlich R, Pezzuto PR, Schwingel PR, Lopes FRA, Rodrigues-Ribeiro M. Deep-sea fishery off southern Brazil: recent trends of the brazilian fishing industry. J Northw Atl Fish Sci. 2003; 31:1-18.

Piercy A, Gelsleichter J, Snelson Jr. FF. Morphological changes in the clasper gland of the Atlantic stingray, Dasyatis sabina, associated with the seasonal reproductive cycle. J Morphol. 2006; 267(1):109-14.

Rigby CL, White WT, Smart JJ, Simpfendorfer CA. Life histories of two deepwater australian endemic elasmobranchs: Argus skate Dipturus polyommata and eastern spotted gummy shark Mustelus walkeri. J Fish Biol. 2016; 88(3):1149-74.

Rincon G. Taxonomia, alimentação e reprodução da raia elétrica Benthobatis sp. (Torpediniformes: Narcinidae) no sul do Brasil. [MSc Dissertation]. Rio Grande, RS: Universidade Federal do Rio Grande; 1997.

Rincon G. Benthobatis kreffit (Brazilian blind electric ray). The IUCN Red List of Threatened Species [Internet]. International Union for Conservation of Nature and Natural Resources; 2004. [updated 2004 Ap 30; cited 2018 Oct 22]. Available from: http://dx.doi.org/10.2305/IUCN.UK.2004.RLTS. T44577A10921737.en

Rincon G, Stehmann MFW, Vooren CM. Results of the research cruises of FRV 'Walther Herwig' to South America. LXXIV. Benthobatis kreffi n. sp. (Chondrichthyes, Rajiformes, Narcinidae), a new deepwater electric ray from off South Brazil and the third species of the genus. Arch Fish Mar Res. 2001; 49(1):45-60.

Rincon G, Mazzoleni RC, Palmeira ARO, Lessa R. Deep-water sharks, rays and chimaeras of Brazil. In: Rodrigues-Filho LF, Sales JBL, editors. Chondrichthyes: multidisciplinary approach. London: Intech; 2017. p.83-112.

Roberts CM. Deep impact: the rising toll of fishing in the deep sea. Trends Ecol Evol. 2002; 17(5):242-45.

Rolim FA, Rotundo MM, Vaske-Júnior T. Notes on the reproductive biology of the brazilian electric ray Narcine brasiliensis (Elasmobranchii: Narcinidae). J Fish Biol. 2015; 89(1):1105-11.

Simpfendorfer CA, Kyne PM. Limited potential to recover from overfishing raises concerns for deep-sea sharks, rays and chimaeras. Environ Conserv. 2009; 36(2):97-103.

Stevens JD, Bonfil R, Dulvy NK, Walker PA. The effects of fishing on sharks, rays, and chimaeras (chondrichthyans), and the implications for marine ecosystems. ICES J Mar Sci. 2000; 57(3):476-94.

Villavicencio-Garayzar CJ. Observaciones sobre la biologia reproductiva de Narcine brasiliensis (Olfers) (Pisces: Narcinidae), em Bahía Almejas, BCS. México. Rev Inves Cien. 1993; 4(1):95-98.

Villavicencio-Garayzar CJ. Taxonomía, abundancia estacional, edad y crecimiento y biología reproductiva de Narcine entemedor Jordan y Starks (Chondrichthyes: narcinidae), en Bahía Almejas, BCS., México. [PhD dissertation]. Nuevo León: Universidad Autónoma de Nuevo León; 2000. 
Vooren CM, Da Silva KG. On the taxonomy of the angel sharks from southern Brazil, with the description of Squatina occulta sp. n. Rev Bras Biol. 1991; 51(3):589-602.

Walker TI. Reproduction in fisheries science. In: Hamlett WC, editor. Reproductive biology and phylogeny of Chondrichthyes: sharks, rays and chimaeras, volume 3. Enfield (NH): Science Publishers Inc.; 2005. p.81-127.

Weigmann S. Annotated checklist of living sharks, batoids and chimaeras (Chondrichthyes) of the world, with focus on biogeographical diversity. J Fish Biol. 2016; 88:837-1037.
Yamaguchi A, Taniuchi T, Shimizu M. Geographic variations in reproductive parameters of the starspotted dogfish, Mustelus manazo, from five localities in Japan and in Taiwan. Environ Biol Fishes. 2000; 57(2):221-33.

Zar JH. Biostatistical Analyses. 5th ed. Upper Saddle River (NJ): Prentice Hall; 2010.

Submitted July 16, 2018

Accepted February 04, 2019 by Lisa Whitenack 
